\title{
Clinical Characteristics and Outcomes among Patients with Covid-19 in Different Regions of the World
}

\author{
Yuanlin Zhou and Huihai Fan \\ Department of Pediatrics, The Sixth People's Hospital of Chengdu, China
}

\begin{abstract}
The SARS-CoV-2 outbreak began in China in December 2019 and rapidly spread globally. Up to July 2020, the number of cases of coronavirus disease 2019 (COVID-19) had been increasing in the USA, Italy, England, Spain and numerous other countries. Patients with this disease in different countries present with different clinical manifestations and different prognosis. The present study aimed to analyse the clinical characteristics of patients infected with SARS-CoV-2 in different regions of the world and provide special advices for the different regions to prevent the spread and a second outbreak of COVID-19.
\end{abstract}

Key Words: COVID-19, SARS-CoV-2, Characteristics, Worldwide.

How to cite this article: Zhou Y, Fan H. Clinical Characteristics and Outcomes among Patients with Covid-19 in Different Regions of the World. J Coll Physicians Surg Pak 2021; 31(JCPSPCR):CR11-CR15.

\section{INTRODUCTION}

The novel coronavirus severe acute respiratory syndrome corona virus-2 (SARS-CoV-2) has been rapidly spreading worldwide, with $>10$ million patients infected with this disease. Up to July 2020, the number of cases of coronavirus disease 2019 (COVID-19) had been increasing in the USA, Italy, England, Spain and numerous other countries. ${ }^{1-4}$ There have been $\sim 13$ million reported cases of this pandemic and $>500,000$ deaths. This disease was originated in Wuhan (Hubei, China). ${ }^{5}$ SARS-CoV-2 has been classified into A, B and C types, according to the gene variants. ${ }^{6}$ Different countries are associated with different SARS-CoV-2 types. European and American patients are mostly infected with the $A$ and $C$ types, while East Asian patients with $B$ type. ${ }^{6}$ Patients with this disease in different countries present with different clinical characteristics including demographics, clinical presentations, comorbidities, and mortalities. It was reported that the median patient age was 52 years in China; ${ }^{7}$ however, the median age of the patients was 40 years in Korea. ${ }^{8}$ The most common symptoms included fever (85.81\%; 399 of $465)$ on admission, followed by cough $(67.10 \%$; 312 of 465$)$ in China. ${ }^{9}$ In Poland, the most common symptoms of COVID-19 were fever (43.78\%; 74 of 169), shortness of breath (36.09\%; 61 of 169), and fatigue (33.73\%; 57 of 169). ${ }^{10}$ However, the most common symptoms were cough $(73.8 \% ; 738$ of 1,000$)$, and fever $(72.8 \% ; 728$ of 1,000$)$, followed by dyspnea $(63.10 \% ; 631$ of 1000 ) in the USA. ${ }^{11}$

Correspondence to: Dr. Fan Huihai, Department of Pediatrics, The Sixth People's Hospital of Chengdu, China E-mail:1935049810@qq.com

Received: August 18, 2020; Revised: November 04, 2020; Accepted: December 05, 2020

DOI: https://doi.org/10.29271/jcpsp.2021.JCPSPCR.CR11
The aim of this review was to assess the characteristics of COVID-19 among different countries. The healthcare data of patients with COVID-19 reported worldwide, which may provide specific suggestions for different countries for the diagnosis and prevention of a second outbreak of COVID-19.

\section{METHODOLOGY}

Literature review was conducted according to preferred reporting items for systematic reviews and meta-analyses guidelines. Medline, Embase and Web of Science databases were searched between December 1, 2019 and April 30, 2020. The search strategy used a combination of MeSH terms and free terms: '2019-nCOV' or 'SARS-CoV-2' or 'COVID19' and 'clinical feature' or 'clinical characteristics' or 'symptom' or 'manifestation'. Searches were limited to literature published in English.

Studies published in English language about the clinical characteristics, including demographics, clinical presentation, comorbidities and mortality of covid19 were selected. The inclusion criteria were full manuscript on the clinical characteristics of patients with SARS-CoV-2 infection. All the patients in these studies were confirmed with SARS-CoV-2 by laboratory test with a positive result on the reverse transcriptase polymerase chain reaction assay for SARS-CoV-2. Articles with incomplete information, review articles, editorial, case reports, ongoing studies and guidelines were excluded. Two investigators reviewed each full-textarticles and finished the studies selection independently. Selected studies were checked together and the disagreements were resolved through consensus. Of the 522 studies reviewed (Figure 1), 27 articles were finally selected. All the patients in the 27 articles were included in this study.

Primary outcome is discharge; and second outcome is remained in hospital. Characteristic included demographics, clinical presentations, comorbidities and mortalities. Data 
about the characteristics including demographics, clinical presentations, comorbidities and mortalities in these studies were extracted by independent investigators. Then the investigators verified the data together. Controversies among investigators were solved by discussion or counselling evidencebased medicine experts in the department. Quality of evidence for randomised studies was assessed according to the cochrane collaboration's tool for assessing risk of bias, and the Newcastle Ottawa scale was used to assess quality of nonrandomised studies.

Five hundred and twenty-two studies were reviewed (Figure 1), and 27 articles were finally selected. The data was analysed through Chi-square test and Fisher's exact test, as appropriate. All statistical analyses were performed using the IBM SPSS version 20.0. Confidence interval $(\mathrm{Cl})$ is $95 \%$. A p-value of less than 0.05 was considered to be statistically significant.

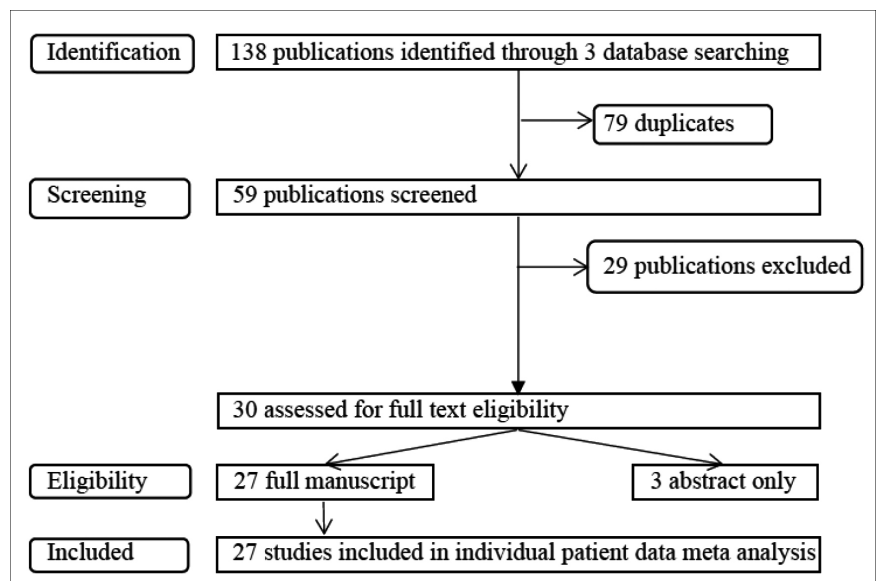

Figure 1: Prisma flow diagram showing the literature research and selection strategy.

\section{RESULTS}

A total of 38,753 patients from 27 studies were included in the presentstudy. Characteristics of thestudies included in the systematic analysis are listed in Table I.

Before March, the COVID-19 outbreak mainly occurred in Asia. A total of $97.51 \%(1,723$ of 1,767$)$ of the COVID-19 cases were located in Asia. Between March and April, 55.25\% (20,425 of 36,968 ) of COVID-19 cases were found in Europe, with Europe becoming the new main site of the COVID-19 outbreak. Concurrently, the disease began to rapidly spread in the USA, with a total of $33.92 \%(12,541$ of 36,968$)$ cases of COVID-19 occurring in the USA.

To assess the characteristics of COVID-19 according to the month of presentation, the clinical manifestations of COVID-19 reported before March and between March and April were analysed (Tablell).

Based on the results, hypertension was among the most common comorbidities. In addition to liver disease and HIV, patients with neurological disorders, chronic lung disease and diabetes mellitus had more COVID-19 in March and April, compared with before March. Fever and cough were the most common symptoms of COVID-19. As regards dyspnea in the context of COVID-19, the proportion of patients with dyspnea between March and April was $58.47 \%$ compared to $14.50 \%$ before the period as above.

To date, the COVID-19 outbreak was mainly spread in Asia, Europe and USA. Hence, the world was divided into three regions (Asia, Europe and USA). The characteristics of patients with COVID-19 were compared among different regions of the world (TableIII).

The compared characteristics included comorbidities, symptoms and outcomes. The comorbidity rates of patients with COVID-19 vary across different areas, ranging between 0.90 and $55.01 \%$. The hypertension rate was $55.01 \%$ in the USA, while it was $44.56 \%$ in Europe and $7.81 \%$ in Asia.

In Asia, only $3.97 \%$ of the patients had heart disease, whereas $17.95 \%$ of patients in Europe and $33.2 \%$ of those in the USA had heart disease. The rates of diabetes mellitus in Europe (15.67\%) and in the USA (28.61\%) were also higher compared with those in Asia (5.37\%). Similar to the aforementioned comorbidities, $15.50 \%$ patients with COVID-19 in Europe and $18.34 \%$ in the USA had chronic lung disease, which was higher compared with the reported percentage in Asia (4.00\%). By contrast, liver disease is more common as comorbidity among Asians (3.24\%).

Next, the symptoms of COVID-19 were compared among Asia, Europe and the USA. The most common symptoms of COVID-19 were fever, coughing and shortness of breath, observed in all regions of the world. However, compared to Asia, the incidence of dyspnea among COVID-19 patients in Europe and the USA is higher. Myalgia is less common in Europe, accounting for only $4.17 \%$, as $26.65 \%$ of the patients in the USA suffered from myalgia. As regards nausea and vomiting, only $4.46 \%$ and $3.55 \%$ had this symptom in Asia and Europe, respectively as compared with $17.80 \%$ in USA. Diarrhea was reported in $6.14 \%$ in Asia and $5.16 \%$ in Europe, whereas $21.32 \%$ of patients with COVID-19 in the USA had diarrhea.

Finally, the outcome of COVID-19 among Asia, Europe and USA were compared. In the present study, $41 \%$ of patients were discharged overall, 74.12\% were discharged in Asia and $40.56 \%$ were discharged in Europe. In the USA, 35.62\% of patients were discharged, which is lower compared with in Asia. A total of $37.54 \%$ of patients in all reported data still remained in hospital to receive treatment, where $18.94 \%$ remained in hospital in Asia, compared to $33.86 \%$ in Europe. Additionally, $51.34 \%$ $(5,925 / 11,541)$ of patients remained in hospital in the USA. The rates of patients remaining in hospital in the USA and Europe were higher compared with in Asia. Around $25.60 \%$ patients died with COVID-19 in Europe, which is higher compared with Asia (6.46\%) and the USA (12.58\%).

\section{DISCUSSION}

The present study described the characteristics of 38,753 patients with COVID-19; worldwide between December $1^{\text {st }} 2019$ and April $30^{\text {th }}, 2020$. This disease was first reported in Wuhan, China and rapidly spread to other countries, including Korea, USA, Italy and Iran, among others. ${ }^{29}$ 
Table I: Characteristics of studies and patients included in the systematic analysis.

\begin{tabular}{|c|c|c|c|c|c|c|c|}
\hline Authors & Time & Region & Sample & Median age & Males (\%) & Stuc & type \\
\hline Zhongwei Xiong ${ }^{7}$ & $\begin{array}{l}\text { February } 9 \text { th to } \\
\text { March 5, } 2020\end{array}$ & China & 421 & $52(39-61)$ & 214 & retrospective study & single-centerstudy \\
\hline Jiangshan Lian ${ }^{9}$ & $\begin{array}{c}\text { January } 17,2020, \text { to } \\
\text { January } 31\end{array}$ & China & 465 & $45(5-88)$ & $243(52.26 \%)$ & retrospective study & multicenter study \\
\hline Marta Colaneri $^{[2}$ & February 21 to 28 & Italy & 44 & 67.5 & 28 & retrospective study & single-center study \\
\hline Dawei Wang ${ }^{13}$ & January 1 to 28 & China & 138 & $56(42-28)$ & 63 & retrospective study & single-center study \\
\hline Mengyao $\mathrm{ji}^{14}$ & January 2 to to 28 & China & 101 & $51.0(37.0-61.0)$ & $48(48 \%)$ & retrospective study & single-center study \\
\hline Michael G Argenziano ${ }^{11}$ & March 1 to April 5 & USA & 1000 & $63.0(50.0-75.0)$ & 596 & retrospective study & single-center study \\
\hline Annemarie B Docherty ${ }^{15}$ & $\begin{array}{c}\text { February } 6 \text { to and } 19 \\
\text { April } 2020 .\end{array}$ & UK & 20133 & $72.9(58.0-82.0)$ & $12068(59.9)$ & $\begin{array}{c}\text { prospective cohort } \\
\text { study }\end{array}$ & multicenter study \\
\hline Christopher M Petrillit ${ }^{16}$ & $\begin{array}{c}\text { March } 12020 \text { to } 8 \\
\text { April }\end{array}$ & USA & 5279 & $54(38-66)$ & $2615(49.5)$ & $\begin{array}{c}\text { prospective cohort } \\
\text { study }\end{array}$ & single-center study \\
\hline Yalei Shanga $^{17}$ & $\begin{array}{c}\text { January to } 2020 \text { to } \\
\text { January } 26\end{array}$ & China & 62 & $41(32-52)$ & $35(56)$ & retrospective study & multicenter study \\
\hline Håkon Ihle-Hansen $^{18}$ & March 9 to 31 & Norway & 42 & 72.5 & 28 & retrospective study & single-center study \\
\hline Helena Barrasa ${ }^{2}$ & March 1 to 31 & Spain & 48 & $63(12)$ & $27(56 \%)$ & $\begin{array}{c}\text { prospective cohort } \\
\text { study }\end{array}$ & multicenter study \\
\hline Mohamad Nikpouraghdam ${ }^{4}$ & $\begin{array}{c}\text { February } 192020 \text { to } \\
\text { April } 152020\end{array}$ & Iran & 2964 & $56(46-65)$ & 1955 & retrospective study & single-center study \\
\hline Guqin Zhang ${ }^{19}$ & $\begin{array}{c}\text { February } 2 \text { to } 10, \\
2020 .\end{array}$ & China & 221 & $55.0(39.0-66.5)$ & 108 & retrospective study & single-center study \\
\hline Ying Sun ${ }^{20}$ & Before April & China & 63 & 47 & 37 & unclear & unclear \\
\hline Simone Piva ${ }^{3}$ & $\begin{array}{c}\text { March } 2 \text { and March } \\
13\end{array}$ & Italy & 33 & $64(59-72)$ & 30 & $\begin{array}{c}\text { prospective cohort } \\
\text { study }\end{array}$ & single-center study \\
\hline Wenjie Yang ${ }^{21}$ & $\begin{array}{c}\text { January } 17 \text { to } \\
\text { February } 10 \\
\end{array}$ & China & 149 & $45.11 \pm 13.35$ & 81 & retrospective study & multicenter study \\
\hline Matthew J Cummings ${ }^{22}$ & $\begin{array}{c}\text { March } 2 \text { to April 1, } \\
2020\end{array}$ & USA & 257 & $62(51-72)$ & 171 & $\begin{array}{c}\text { prospective cohort } \\
\text { study }\end{array}$ & multicenter study \\
\hline Yalei Shang $^{17}$ & $\begin{array}{c}\text { January 10th } 2020 \text { to } \\
\text { March }\end{array}$ & China & 307 & $46(33,55)$ & 164 & $\begin{array}{c}\text { prospective cohort } \\
\text { study }\end{array}$ & multicenter study \\
\hline Chaolin Huang & January 2, 2020 & China & 41 & $49.0(41.0-58.0)$ & 30 & $\begin{array}{c}\text { prospective cohort } \\
\text { study }\end{array}$ & single-center study \\
\hline Nanshan Chen ${ }^{23}$ & \begin{tabular}{|c} 
January 1 to Jan 20 \\
2020
\end{tabular} & China & 99 & $55.5(13.1)$ & $67(68 \%)$ & retrospective study & single-centre study \\
\hline Eu Suk Kim ${ }^{8}$ & \begin{tabular}{|c|} 
January 192020 to \\
February 17,2020 \\
\end{tabular} & Korea & 28 & $42.6 \pm 13.4$ & $15(53.6)$ & $\begin{array}{c}\text { prospective cohort } \\
\text { study }\end{array}$ & multicenter study \\
\hline Rui Huang ${ }^{24}$ & $\begin{array}{l}\text { January } 22,2020 \text { to } \\
\text { February } 10,2020\end{array}$ & China & 202 & $44.0(33.0,54.0)$ & $116(57.4)$ & retrospective study & multicenter study \\
\hline Yiwu Zhou ${ }^{25}$ & $\begin{array}{c}\text { January } 20,2019, \\
\text { and February } 8, \\
2020 .\end{array}$ & China & 366 & $43(31.8-51.0)$ & $207(56.6)$ & retrospective study & multicenter study \\
\hline Jeremy A W Gold ${ }^{26}$ & $\begin{array}{c}\text { March } 1 \text { to March 30, } \\
2020\end{array}$ & USA & 305 & $60(46-69)$ & $49.50 \%$ & $\begin{array}{c}\text { prospective cohort } \\
\text { study }\end{array}$ & multicenter study \\
\hline Błażej Nowak ${ }^{10}$ & $\begin{array}{c}\text { March } 16,2020 \text { and } \\
2020 / 4 / 7 \\
\end{array}$ & Poland & 169 & $63.7(19.6)$ & 87 & retrospective study & single-center study \\
\hline Safiya Richardson ${ }^{27}$ & $\begin{array}{l}\text { March 1, 2020, and } \\
\quad \text { April 4, 2020 }\end{array}$ & USA & 5700 & $63(52-75)$ & 3437 & unclear & multicenter study \\
\hline Kyung Soo Hong ${ }^{28}$ & Before March 29th & Korea & 98 & $55.4 \pm 17.1$ & 38.00 & retrospective study & single-center study \\
\hline
\end{tabular}

The disease characteristics, such as admission rates, fatality rates and symptoms, vary widely among different regions of the world. ${ }^{9-11}$

The aim of the present study was to comprehensively analyse the characteristics of COVID-19 and analyse the risk factors of COVID-19; in different regions of the world providing personal suggestions for the different regions. It was observed that patients in the USA had the highest rate of comorbidities such as hypertension, heart disease, chronic lung disease, and diabetes mellitus; whereas in Asia, the most common comorbidities were liver diseases and HIV infection. This finding indicates that Europe and the USA must improve the screening and preventive measures for COVID-19 in patients with hypertension, heart disease, chronic lung disease and diabetes mellitus, particularly those with hypertension and/or heart diseases. As regards the clinical symptoms, fever and cough are the most common symptoms worldwide; whereas, the incidence of dyspnea is higher among patients with COVID-19 in Europe and the USA. This finding indicates that, in addition to fever and cough, screening for dyspnea is important for preventing the spread of SARS-CoV-2. This phenomenon may be partially attributed to the high proportion of related comorbidities in patients from Europe and the USA. 
Table II: Characteristics of patients with COVID-19 before March and March-April.

\begin{tabular}{|c|c|c|c|}
\hline & Before March & March-April & $\mathbf{p}$ \\
\hline \multicolumn{4}{|l|}{ Comorbidities } \\
\hline Heart diseases & $8.41 \%$ & $21.75 \%$ & 0.000 \\
\hline Neurologic disorder & $2.94 \%$ & $11.96 \%$ & 0.000 \\
\hline Chronic lung disease & $1.94 \%$ & $15.37 \%$ & 0.000 \\
\hline Diabetes mellitus & $7.15 \%$ & $19.17 \%$ & 0.000 \\
\hline Hypertension & $18.23 \%$ & $39.68 \%$ & 0.000 \\
\hline Liver disease & $3.27 \%$ & $1.66 \%$ & 0.000 \\
\hline Malignancy & $2.86 \%$ & $5.52 \%$ & 0.000 \\
\hline Kidney disease & $1.56 \%$ & $8.51 \%$ & 0.000 \\
\hline HIV & $2.24 \%$ & $0.47 \%$ & 0.000 \\
\hline \multicolumn{4}{|l|}{ Symptoms } \\
\hline Fever & $74.98 \%$ & $62.77 \%$ & 0.000 \\
\hline Cough & $52.53 \%$ & $63.85 \%$ & 0.000 \\
\hline Sputum & $57.05 \%$ & $8.89 \%$ & 0.000 \\
\hline Myalgia & $13.52 \%$ & $23.28 \%$ & 0.000 \\
\hline Fatigue & $27.65 \%$ & $23.11 \%$ & 0.047 \\
\hline Short of breath & $14.50 \%$ & $58.47 \%$ & 0.000 \\
\hline Nausea and vomiting & $4.78 \%$ & $13.21 \%$ & 0.000 \\
\hline Diarrhea & $7.23 \%$ & $13.89 \%$ & 0.000 \\
\hline Headache & $9.22 \%$ & $9.03 \%$ & \\
\hline Rhinorrhoea & $3.33 \%$ & $7.50 \%$ & 0.002 \\
\hline Sore throat & $11.86 \%$ & $9.10 \%$ & 0.051 \\
\hline \multicolumn{4}{|l|}{ Clinical outcomes } \\
\hline Remains in hospital & $62.55 \%$ & $36.70 \%$ & 0.000 \\
\hline Discharged & $30.94 \%$ & $43.57 \%$ & 0.000 \\
\hline Died & $3.88 \%$ & $4.48 \%$ & 0.478 \\
\hline
\end{tabular}

Table III: Characteristics of COVID-19 patients among Asia, Europe and America.

\begin{tabular}{|c|c|c|c|c|}
\hline & Asia & Europe & America & $\mathbf{p}$ \\
\hline \multicolumn{5}{|l|}{ Comorbidities } \\
\hline Heart diseases & w3.97\% & $17.95 \%$ & $33.20 \%$ & 0.000 \\
\hline Neurologic disorder & $10.45 \%$ & $11.99 \%$ & $11.03 \%$ & 0.209 \\
\hline Chronic lung disease & $4.00 \%$ & $15.50 \%$ & $18.34 \%$ & 0.000 \\
\hline Diabetes mellitus & $5.37 \%$ & $15.67 \%$ & $28.61 \%$ & 0.000 \\
\hline Hypertension & $7.81 \%$ & $44.56 \%$ & $55.01 \%$ & 0.000 \\
\hline Liver disease & $3.24 \%$ & $1.88 \%$ & $1.05 \%$ & 0.000 \\
\hline Malignancy & $1.34 \%$ & $5.70 \%$ & $6.53 \%$ & 0.000 \\
\hline Kidney disease & $0.90 \%$ & $8.41 \%$ & $10.55 \%$ & 0.000 \\
\hline HIV & $2.25 \%$ & $0.27 \%$ & $1.04 \% a$ & 0.000 \\
\hline Fever & $72.08 \%$ & $62.12 \%$ & $72.47 \%$ & 0.000 \\
\hline Cough & $57.08 \%$ & $63.76 \%$ & $71.68 \%$ & 0.000 \\
\hline Myalgia & $15.30 \%$ & $4.17 \%$ & $26.65 \%$ & 0.000 \\
\hline Short of breath/dyspnea & $12.38 \%$ & $59.94 \%$ & $65.31 \%$ & 0.000 \\
\hline Nausea and vomiting & $4.46 \%$ & $3.55 \%$ & $17.80 \%$ & 0.000 \\
\hline Diarrhea & $6.14 \%$ & $5.16 \%$ & $21.32 \%$ & 0.000 \\
\hline \multicolumn{5}{|l|}{ Clinical outcomes } \\
\hline Remains in hospital & $18.94 \%$ & $33.86 \%$ & $51.34 \%$ & 0.000 \\
\hline Discharged & $74.12 \%$ & $40.56 \%$ & $35.62 \%$ & 0.000 \\
\hline Died & $6.46 \%$ & $25.60 \%$ & $12.58 \%$ & 0.000 \\
\hline
\end{tabular}

Patients in Asia had higher rates of discharge and lower rates of mortality compared with Europe and USA $(p=0.000)$. In the USA, although the rate of discharge was the lowest among the three areas, the mortality of patients with COVID-19 was not the highest. A possible explanation may be the advanced medical technology available in the USA. However, the mortality rate of patients with COVID-19 in Europe was very high. The higher mortality rates of COVID-19 in Europe and USA may be due to the high rate of comorbidities, suggesting that more attention should be paid to patients with comorbidities, such as more health monitoring, more protective equipment, more supportive treatment etc.

\section{CONCLUSION}

COVID-19 has higher prevalence among patients with comorbidities, such as heart disease, chronic lung disease, and hypertension in the USA and Europe compared with Asia $(p=0.000)$. Liver disease and HIV were risk factors associated with COVID-19 in Asia. Hence, patients with HIV and liver disease also should be closely followed in Asia to prevent the spread and a possible second outbreak of COVID-19. Furthermore, not only the symptoms such as fever and cough should be monitored; but also the dyspnea, myalgia, nausea, vomiting, and diarrhea should be screened in Europe and USA. The mortality rates in Europe and USA were significantly higher compared with that in Asia.

\section{PATIENTS' CONSENT:}

The consents of the patients were taken prior to the writing of the manuscript.

\section{CONFLICT OF INTEREST:}

The authors declared no conflict of interest.

\section{AUTHORS' CONTRIBUTION:}

$\mathrm{ZY}, \mathrm{FH}$ : Contributed to the design of the work and acquisition, analysis, or interpretation of data for the work together. They worked on the drafting of the work or revising it critically for important intellectual content and approved the version to be published. They agreed to be accountable for all aspects of the work in ensuring that questions related to the accuracy or integrity of any part of the work are appropriately investigated and resolved.

\section{REFERENCES}

1. Aggarwal S, Garcia-Telles N, Aggarwal G, Lavie C, Lippi G, Henry BM. Clinical features, laboratory characteristics, and outcomes of patients hospitalised with coronavirus disease 2019 (COVID-19): Early report from the United States. Diagnosis (Berlin, Germany) 2020; 7(2):91-6. doi: 10.1515/ dx-2020-0046.

2. Barrasa H, Rello J, Tejada S, Martín A, Balziskueta G, Vinuesa C, et al. SARS-CoV-2 in spanish intensive care units: Early experience with 15-day survival in Vitoria. Anaesth Critical Care Pain Med 2020; 39(5):553-61. doi: 10.1016/ j.accpm.2020.04.001.

3. Piva S, Filippini M, Turla F, Cattaneo S, Margola A, Margola S $D E$, et al. Clinical presentation and initial management critically ill patients with severe acute respiratory syndrome coronavirus 2 (SARS-CoV-2) infection in Brescia, Italy. J Critical Care 2020; 58:29-33. doi: 10.1016/j.jcrc.2020.04.004.

4. Nikpouraghdam M, Farahani AJ, Alishiri G, Heydari S, Ebrahimnia M, Samadinia $\mathrm{H}$, et al. Epidemiological characteristics of coronavirus disease 2019 (COVID-19) patients in IRAN: A single center study. J Clin Virol 2020; 127: 104378. doi: 10.1016/j.jcv.2020.104378.

5. Huang C, Wang Y, Li X, Ren L, Zhao J, Hu Y, et al. Clinical features of patients infected with 2019 novel coronavirus in Wuhan, China. Lancet 2020; 395(10223):497-506. doi: 
10.1016/S0140-6736(20)30183-5.

6. Forster P, Forster L, Renfrew C, Forster M. Phylogenetic network analysis of SARS-CoV-2 genomes. Proc Natl Acad Sci U $S$ A 2020; 117(17):9241-9243. doi: 10.1073/pnas. 2004999117.

7. Xiong Z, Xin C, Xiong Z, Cai Y, Zhou K, Xie C, et al. Clinical characteristics and outcomes of 421 patients with COVID-19 treated in a mobile cabin hospital. Chest; 2020; 158(3): 939-46. doi: 10.1016/j.chest.2020.05.515.

8. Kim ES, Chin BS, Kang CK, Kim NJ, Kang UM, Choi JP, et al. Clinical course and outcomes of patients with severe acute respiratory syndrome coronavirus 2 Infection: A preliminary report of the first 28 patients from the korean cohort study on COVID-19. J Korean Med Sci 2020; 35(13):e142. doi: 10.3346/jkms.2020.35.e142.

9. Lian J, Jin X, Hao S, Jia H, Cai H, Zhang X, et al. Epidemiological, clinical, and virological characteristics of 465 hospitalised cases of coronavirus disease 2019 (COVID-19) from Zhejiang province in China. Influenza Respir Virus 2020; 14(5):564-74 doi: 10.1111/irv.12758.

10. Nowak B, Szymański P, Pańkowski I, Szarowska A, Zycinska K, Rogowski W, et al. Clinical characteristics and short-term outcomes of patients with coronavirus disease 2019: A retrospective single-center experience of a designated hospital in Poland. Polish Archives Int Med 2020; 130(5): 407-411. Doi: 1020452/pamw.15361.

11. Argenziano M G, Bruce $S \mathrm{~L}$, Slater $C L$, Tiao JR, Baldwin $M R$, Barr RG, et al. Characterisation and clinical course of 1000 patients with coronavirus disease 2019 in New York: retrospective case series. BMJ (Clinical research ed) 2020; 369:m1996.

12. Colaneri M, Sacchi P, Zuccaro V, Biscarini S, Sachs M, Roda S, et al. Clinical characteristics of coronavirus disease (COVID-19) early findings from a teaching hospital in Pavia, North Italy, 21 to 28 February 2020. European Communicable Dis Bulletin 2020; 25(16).

13. Wang D, Hu B, Hu C, Zhu F, Liu X, Zhang J, et al. Clinical characteristics of 138 hospitalised patients with 2019 novel coronavirus-infected pneumonia in Wuhan, China. JAMA 2020; 323(11): 1061-1069. Doi: 10.1001/jama.2020.1585.

14. Ji M, Yuan L, Shen W, Lv J, Li Y, Li M, et al. Characteristics of disease progress in patients with coronavirus disease 2019 in Wuhan, China. Epidem Infect 2020; 148:e94. Doi: 10.1017/ S09502688200009772020148.

15. Docherty $A B$, Harrison EM, Green $C A$, Hardwick HE, Pius R, Norman L, et al. Features of 20133 UK patients in hospital with covid-19 using the ISARIC WHO clinical characterisation protocol: Prospective observational cohort study. BMJ 2020; 369:m1985. doi: 10.1136/bmj.m1985.

16. Petrilli CM, Jones SA, YangJ, Rajagopalan H, O'Donnell L, Chernyak $Y$, et al. Factors associated with hospital admission and critical illness among 5279 people with coronavirus disease 2019 in New York City: Prospective cohort study. BMJ 2020; 369:m1966. doi: 10.1136/bmj.m1966.

17. Shang $Y, X u$ C, Jiang F, Huang R, Li Y, Zhou Y, et al. Clinical characteristics and changes of chest CT features in 307 patients with common COVID-19 pneumonia infected SARS-CoV-2: A multicenter study in Jiangsu, China. Int J Infec Dis
2020; 96: 157-62. doi: 10.1016/j.jijid.2020.05.006.

18. Ihle-Hansen $H$, Berge $T$, Tveita A, Rønning EJ, Ernø PE, Andersen EL, et al. COVID-19: Symptoms, course of illness and use of clinical scoring systems for the first 42 patients admitted to a Norwegian local hospital. Tidsskr Nor laegefore 2020; 140(7). doi: 10.4045/tidsskr.20.0301.

19. Zhang G, Hu C, Luo L, Fang F, Chen Y, Li J, et al. Clinical features and short-term outcomes of 221 patients with COVID-19 in Wuhan, China. J Clin Virol 2020; 127:104364. doi: 10.1016/j.jcv.2020.104364.

20. Sun Y, Dong Y, Wang L, Xie H, Li B, Chang C, et al. Characteristics and prognostic factors of disease severity in patients with COVID-19: The Beijing experience. J Autoimmunity 2020; 112:102473. doi: 10.1016/j.jaut. 2020.102473.

21. Yang W, Cao Q, Qin L, Wang X, Cheng Z, Pan A, et al. Clinical characteristics and imaging manifestations of the 2019 novel coronavirus disease (COVID-19): A multi-center study in Wenzhou city, Zhejiang, China. J Infec 2020; 80(4):388-93. doi: 10.1016/j.jinf.2020.02.016.

22. Cummings MJ, Baldwin MR, Abrams D, Jacobson D, Meyer BJ, Balough $E M$, et al. Epidemiology, clinical course, and outcomes of critically ill adults with COVID-19 in New York City: A prospective cohort study. Lancet 2020; 395 (10239):1763-70. doi: 10.1016/S0140-6736(20)31189-2.

23. Chen N, Zhou M, Dong X, Qu J, Gong F, Han Y, et al. Epidemiological and clinical characteristics of 99 cases of 2019 novel coronavirus pneumonia in Wuhan, China: A descriptive study. Lancet 2020; 395(10223):507-13. doi: 10.1016/S01406736(20)30211-7.

24. $X u X W, W u X X$, Jiang $X G, X u K J$, Ying LJ, Ma CL, et al. Clinical findings in a group of patients infected with the 2019 novel coronavirus (SARS-Cov-2) outside of Wuhan, China: Retrospective case series. BMJ (Clinical research ed) 2020; 368:m606. doi: 10.1136/bmj.m606.

25. Zhou Y, He Y, Yang H, Yu H, Wang T, Chen Z, et al. Development and validation a nomogram for predicting the risk of severe COVID-19: A multi-centre study in Sichuan, China. PloS one 2020; 15(5):e0233328. doi: 10.1371/journal. pone.023 3328.

26. Gold JAW, Wong KK, Szablewski CM, Patel PR, Rossow J, da Silva J, et al. Characteristics and clinical outcomes of adult patients hospitalised with COVID-19 - Georgia, March 2020. MMWR Morbidity And Mortality Weekly Rep 2020; 69(18): 545-50. doi: 10.15585/mmwr.mm6918e1.

27. Richardson S, Hirsch JS, Narasimhan M, Crawford JM, McGinn $\mathrm{T}$, Davidson KW, et al. Presenting characteristics, comorbidities, and outcomes among 5700 patients hospitalised with COVID-19 in the New York City Area. JAMA 2020; 323(20): 2052-9. doi: 10.1001/jama.2020.6775.

28. Hong KS, Lee KH, Chung JH, Shin KC, Choi EY, Jin HJ, et al. Clinical features and outcomes of 98 patients hospitalized with SARS-CoV-2 infection in daegu, South Korea: A brief descriptive study. Yonsei Med J 2020; 61(5):431-7. doi: 10.3349/ ymj.2020.61.5.431.

29. Guan WJ, Ni ZY, Hu Y, Liang WH, Ou CQ, He JX, et al. Clinical characteristics of coronavirus disease 2019 in China. N Engl J Med 2020; 382(18):1708-20. doi: 10.1056/NEJMoa2002032. 